\title{
Critical Race Theory, Wrongful Convictions and Disparate Exonerations of Minority and White Youths in the United States
}

\author{
Kenneth A. Jordan \\ Professor Department of Social \& Behavioral Sciences, Savannah State University, Savannah, Georgia, United States.
}

\author{
Article Details \\ Article Type: Review Article \\ Received date: $22^{\text {nd }}$ July, 2021 \\ Accepted date: $12^{\text {th }}$ October, 2021 \\ Published date: $14^{\text {th }}$ October, 2021
}

*Corresponding Author: Kenneth A. Jordan, Professor Department of Social \& Behavioral Sciences, Savannah State University, Savannah, Georgia, United States. E-mail: jordank@savannahstate.edu

Citation: Jordan, K.A. (2021). Critical Race Theory, Wrongful Convictions and Disparate Exonerations of Minority and White Youths in the United States. J Ment Health Soc Behav 3(2):148. https://doi.org/10.33790/jmhsb1100148

Copyright: (C2021, This is an open-access article distributed under the terms of the Creative Commons Attribution License 4.0, which permits unrestricted use, distribution, and reproduction in any medium, provided the original author and source are credited.

\begin{abstract}
Race is central to every aspect of the criminal justice system in the United States. According to the U.S. Bureau of Justice Statistics (BJS), in 2013, black males accounted for 37 percent of the total male prison population in the United States with white males accounting for only 32 percent followed by Hispanic males at 22 percent respectively. In the general population, however, Black males comprise only 6 percent of the total males population while White males constitute 31 percent of the total males population in the U.S. followed by Hispanic males who make up 8.4 percent of the total male population. The conviction of innocent defendants is quite disturbing regardless of race or ethnicity. Nothing is more glaring of this phenomenon than when one considers that African American males make up only 6 percent of the total males population but are reported as committing 52 percent of the murders. It is widely known that the lack of formal processes and constitutional due process in the juvenile justice system and the potential for substantial deprivations of children's liberty through extensive periods of incarceration has been pervasive, persistent, and ongoing in this country (Juvenile Justice Center, 2020). Critical Race Theory has done nothing less than shed more light on the predictability of youth treatment landing them behind bars for lengthy prison sentences for crimes in which they frequently did not commit. Critical Race Theory falls short, however, of offering any plausible explanations for why so many minority youths are falsely imprisoned. Other theories must be considered as plausible explanations for this phenomenon of disparate treatment between the races whether it be police shooting, disparate convictions and incarceration or racial profiling. These theories include Racial Conflict Theory, Racial Threat Theory and Petit Apartheid Theory. The core idea of Critical Race Theory is that racism does not stop at the individua level, but it is systemic or system-wide and ingrained in our policies, in our legal systems and institutions. Critical Race Theory has absolutely nothing to do with "punishing kids for their skin color or making young white kids feel guilty for being white no more than critical thinking is criticizing someone for well thinking. Critical Race Theory is a dialogue for raising awareness of policies and practices that have had a disproportionately negative impact on racial minorities in particular and youth in general irrespective of race. There were 2,310 people serving life-without-parole sentences for crimes committed as juveniles (known as JLWOP) at the end of 2016. This study examines the data extracted from the national registry of exonerations in the United States on every known exoneration from 1989 to 2020 . Contributing factors to such
\end{abstract}

disparate convictions among young African American males such as false confessions, mistaken identity, false accusations, witness tampering, perjury or false statements under oath particularly by police officers, prosecutorial misconduct, inadequate legal defense, and mistaken witness identification are highlighted and discussed as major contributing factors to the exoneree's eventual release. This study assumes the position that, although all lives matter, it appears that African American Male Youths are more disproportionate among the population of those exonerated for crimes that they did not commit. The study proffers policy implications and policy changes that appear to be viable solutions to this egregious and tragic abuse of humankind.

Key Words: Critical Race Theory (CRT), Racial Conflict Theory, Racial Threat Theory and Petit Apartheid Theory, Criminal Justice Reform, Black Lives Matter, Absolute immunity, Qualified immunity, Win with Justice, Racial Profiling.

\section{Introduction}

Wrongful convictions are caused by both systemic flaws in our criminal justice system and by external variables, including subtle factors that subconsciously affect who we perceive as guilty or innocent and how the criminal justice community conduct investigations. This community of law enforcement personnel include everyone from the cop on the street who use their administrative discretion to make the arrest to the attorney who represent their respective clients and the district attorneys who make the decision to bring the official charges to the judges who eventually hand out the sentences. These human factors suggest that race has an impact in our court outcomes [1]. The term wrongful conviction in this paper refers to those people who were convicted but are "probably innocent of any crime." All of the available evidence proves that Blacks are overrepresented at every level of the criminal justice system but nowhere more glaring than in the percentage of known wrongful convictions during the past 100 years [2]. Half of all defendants or 50 percent of those exonerated for murder since 1986 $(380,762)$ are African Americans who make up only 13 percent of the population of the United States, [3]. For the population at large, that number for black defendants is seven times the rate for whites, who constitute 64 percent of the population, but comprise only 36 percent of murder exonerations [3]. Much of this racial disparity can be traced to a comparable disparity in murder convictions as African Americans are more than seven times more likely to be imprisoned for murder than their white counterparts (Ibid, 2017). It appears safe to say that at no other time in our American history has 
Critical Race Theory been a more salient theme than it is today. In the wake of the Black Lives Matter movement and the devaluing of black lives as demonstrated by the consistent behavior of police officers who perpetrate human atrocities against African American in alarming numbers, Critical Race Theory has gained more momentum than ever before. Studies examining exoneration decisions are relatively few, which gave rise to this study to examine legal, racial, extra-legal and other factors contributing to the wrongful conviction and legal detention of African American youth in the United States. This study uses data compiled by the National Exoneration Registry to examine the wrongful and unlawful convictions of Youth who have been exonerated after lengthy stays in prison due to a set of factors ranging from misidentification to legal misconduct and out right perjury.

\section{The Literature}

In America today, an extended police record and/or prison sentence for most African Americans is tantamount to a death sentence. Once you become a convicted felon in America, you have no more rights than you had while you were enslaved on America's plantations as indentured servants [4]. "After all, with a criminal conviction often comes a lifetime of discrimination in employment, housing, and in some states in the United States, a permanent loss of voting rights" [5]. The Netflix miniseries "When They See Us" is a documentary on the exonerated 5 known as the Central Park five. These were five Black and Latino teenagers from Harlem who were coerced into providing false confessions and then wrongly convicted of raping a white woman who was jogging in New York's s Central Park in 1989. The boys served between six and 13 years before a serial rapist admitted to the crime and his confession was supported by DNA evidence. In 2002, the convictions were vacated and in 2015, New York City settled with the five for $\$ 40$ million dollars [6]. While this money may provide some consolation or solace to the families for the pain, suffering, and hurt of being without the company and presence of their loved ones, it can never be overstated that no dollar amount can be attached to the loss of years and quality of life and human experiences endured while sitting behind bars in any jail or prison system especially for a crime in which they did not commit. The story of the Exonerated 5 brought to light the influence of the media on the criminal justice system in American, but one of the most memorable moments of the case was actually an ad taken out in the New York Times on May 1, 1989 where real estate developer Donald Trump paid $\$ 85,000$ for a full-page ad calling for the death penalty for the five boys prior to their trial [6]. "Sadly, the story of the exonerated 5 is not a unique one in American. What happened to those boys is often compared to the story of The Scottsboro Boys in 1931, where nine Black teenage boys from 13 to 21 years of age, entirely innocent of any crime, were framed and convicted on false charges of "rape" and condemned to death in the Alabama electric chair for being falsely accused of rape by two white women. They were tried by an all- white, all-male jury who quickly sentenced 8 of them to death while the trial of the youngest, a 13-year-old child, ended in a hung jury when one juror favored life imprisonment rather than death. After four years in prison, all charges were dropped against 6 of the boys, a seventh boy was paroled and two returned to prison after violating their parole. In 2013, they all finally received justice as an Alabama Judge pardoned the remaining men who had not already been pardoned. These are only a few of a litany of cases, many of them decades long, that have represented racial injustice in the Deep South. One of the defendants received a pardon before his death in 1976. At that time, he was the only Scottsboro Boy known to be alive. Nothing was done for the others because state law did not permit posthumous pardons." This case has, over the years, inspired books, and films, as well as a Broadway musical [7]. African Americans are incarcerated in state prisons across this country at more than five times the rate of whites (5:1 ratio) while African J Ment Health Soc Behav

Volume 3. 2021. 148
Americans comprise only 13 percent of the population of the United States as a whole. There can be no doubt about it: Young people, regardless of race, are simply more likely to be wrongfully convicted than adults. There are many reasons for this, many of which are rooted in the special developmental vulnerabilities of children. "Children and teenagers are categorically more suggestible, compliant, and vulnerable to outside pressures than adults. They are less able to weigh risks and consequences; less likely to understand their legal rights; and less likely to understand what attorneys do or do not do or how attorneys can help them. Notwithstanding, the United States stands alone as the only nation in the free world that sentences people to life without parole for crimes committed before turning 18 " (Rover, 2021). Critical questions regarding the quality of life among young male adults must be addressed by our criminal justice system. First, why is one third of the prison population in America black, regardless of the crime, when African Americans constitute only 13 percent of the total population as a whole? Second, why do police officers who conduct these outrageous programs of framing innocent drug defendants concentrate on African Americans? Third, why were so many innocent black defendants arrested for drug possession when there is no reason to believe that African Americans are more likely than whites to use illegal drugs? Fourth, why are African American teen age boys convicted and imprisoned for murder, attempted murder, and accessory to murder at five times the rate as their white male teen age counterparts? The simple answer, according to Samuel Gross and his colleagues, is "Because that's what they do in all aspects of drug-law enforcement. Guilty or innocent, they always focus disproportionately on African Americans. Judging from exonerations, innocent black people are about seven times more likely to be convicted of murder than innocent white people. African American prisoners who are convicted of murder are about 50 percent more likely to be innocent than other convicted murderers [3]. Part of that disparity is tied to the race of the victim. African Americans imprisoned for murder are more likely to be innocent if they were convicted of killing white victims. Only about 15 percent of murders by African Americans have white victims, but 31 percent of innocent African American murder exonerees were convicted of killing white people. One of the theories that attempt to explain this practice in knowns as Racial Threat Theory. Racial threat theory was developed as a way to explain how population composition influences discriminatory social control practices and has become one of the most acknowledged frameworks for explaining racial disparity in criminal justice outcomes. The racial threat hypothesis originated in Blalock 1967, which argued that as the relative size of racial and ethnic minority group increases, members of the majority group perceive a growing threat [8]. Researchers have since extended Blalock's original propositions to include criminal threat - that is, a larger black population fosters fear of crime. Racial Conflict Theory presents another potential explanation to considered in evaluating crime data. Race-based conflict theory posits that the criminal justice system is skewed in favor of members of the socially dominant white race, while biased against members of Hispanic, black, or indigenous racial and ethnic groups. Conflict theories of criminal justice look at criminal laws as a means by which more prosperous and powerful social groups exercise control and containment over socially disadvantaged groups [9]. Because conflicts exist in society, conflict theorists view the law, police, and other governmental agents as coercive weapons used to promote the interests of powerful groups to the detriment of the powerless [9]. Most wrongful convictions, the primary emphasis of this study, are never discovered and there is no direct measure of the number of all convictions of innocent murder defendants; however, judging from exonerations, half of those innocent murder defendants are African Americans [3]. Of the many costs that the War on Drugs inflict on the black community, the practice of deliberately charging innocent defendants 
with fabricated crimes may be the most shameful"[3]. In 1787, black males were treated as "nonpersons" on slave plantations; in 1987, they were increasingly ignored as "invisible persons" on " welfare plantations" [10]. Today, they are increasingly and disproportionately singled out and brutally murdered by white police officers such as the case with George Floyd and Ahmadu Arbery or tried as adults frequently for crimes in which they did not commit and sentenced to life in prison usually at the insistence of an all- white jury. Conflict theorists suggest that race- based conflict is inevitable whenever there exists little or no relationships between the police and community residents. Therefore, they are predisposed to operate with a legacy of mistrust towards each other [9]. Conflict theory holds that power and authority are essential for maintaining social, political, and economic inequality, as well as exerting control over those who are viewed as being part of the surplus population Turk [11-13]. "These theorists do not believe that equality exists or that all people are treated fairly under the law, but rather the law, and the justice system (e.g., police, courts, and corrections, are biased in favor of powerful groups." [9]. Critical Race Theory (CRT) evolved in the late 1980s. When the Civil Rights Movement stalled, new theories were needed to cope with emerging forms of institutional or "colorblind" racism and a public that seemed tired of hearing about race [14]. Conflict theories were effective in unmasking the true nature of law, order, and the use of authority during the turbulent periods of the civil rights struggle and other movements that transformed the social fabric of the American society. CRT was a response to the mid-1970s conservative, reactionary attack on the achievements of the civil rights struggle. and historically constructed cultural force in American society [15]. This racism expresses itself in popular culture by believed myths, stories, legal rules, and the institutional disposition of prestige and power via the concept of whiteness [15]. This racism is also systemic. It expresses itself in all aspects of the criminal justice system from the actions and the behavior of local police officers on the street, to the district attorney, the prosecuting attorney, and the presiding judge.Local police officers possess a great deal of administrative discretion and frequently, because of their racial and cultural biases, there is no explanation for their propensity for wanting to lock people of color away and throw away the key. Critical race theorists have insisted that no benefit could flow from interracial dialogue on charges of racism or conditions besetting black people [16]. Harvard law professor and critical race theory icon Derrick Bell proclaimed that a "racist society continues to exert dominion over black men and their maleness in ways more subtle but hardly less castrating than during slavery" [16]. One of the best-known Afro centrists of our time, Molefi Asante, held that "there is no such thing as black racism against whites; racism is based on fantasy while black views of whites ae based on fact" [16]. "While it is difficult to measure the extent of racial profiling, using race to screen for problematic individual behaviors, it is clear that it continues to take place in policing." [17]. There is no rational explanation for why so many black men are framed at the hands of racist police officers whether it be for murder, sexual assault, armed robbery, or drug trafficking. For example, throughout the state of North Carolina - the state that keeps the most comprehensive records of traffic - a 2015 investigations by the New Your Times revealed "wide racial differences in measure after measure of police conduct" [18]. Police patrol and enforce communities at different rates, sending more officers into Black and Latino neighborhoods, leading to more arrests and their resulting disadvantages in those areas [19] Subconscious bias has no rational explanation. Petit Apartheid Theory offers some discussion for this phenomenon. This theory refers to the hidden, informal types system. Notably, these informal practices are not included in most evaluations of racial discrimination. Petit apartheid refers to the Critical race theory argues that white racism is a hegemonic, socially, of racist bias that permeates various stages of the criminal justice

"everyday slights, insults, rough or brutal treatment and unnecessary stops, questions, and searches of blacks..." and posits that such treatment has a cumulative effect on every stage of criminal justice practices and proceedings. Petit Apartheid in the U.S. Criminal Justice System brings long-overdue attention to the reality of how race affects criminal justice processing [20]. The authors make a strong case that further research, new policy, and ultimately new practices are needed to stem the tide of racial bias in the criminal justice system.Famed black psychologists William Grier and Price Cobbs held that "it is necessary for a black man in America to develop distrust of his fellow white citizens...If he does not so protect himself, he will live a life of such pain and shock as to find life itself unbearable. For his own survival, then, he must develop a cultural paranoia in which every white man is a potential enemy... and every social system is against him unless he personally finds out differently"[16]. Social activist, Bell Hooks, writes that "the cumulative effects of the perception of unending racism was rage. "My rage burns....in my psyche with an intensity that creates clarity. It is a constructive healing rage... if rage can produce such benefits internally, would it not be useful to cultivate it externally"?[16]. That rage was exemplified by the 1994-1995 murder trial of black former football legend O.J. Simpson, dubbed "The Trial of the century." When Simpson's attorney Johnny Cochran attempted to introduce evidence of Detective Mark Fuhrman's use of the N-word to show the latter's racism. Los Angeles County assistant district attorney Chris Darden strongly objected, prompting attorney Cochran to hit the roof calling Darden's argument "the most incredible remarks I've heard in the thirty-two years I've been practicing law." Cochran went on to proclaim that "it's demeaning to our system of jurisprudence to say that African Americans who've lived under oppression for 200 -plus years in this country cannot work in the mainstream. African Americans live with offensive words, offensive looks, offensive treatment every day of their lives... and yet they still believe in this country “ [16]. Darden backed down and Cochran's testimony was admitted, which probably contributed to Simpson's acquittal [16]. The point has to be made that Detective Mark Furman was the same individual that planted false DNA evidence at Simpson's home to convince a jury of his guilt. As was stated earlier by Gross, "This is what they do." By demonizing Simpson, many felt they were proving the moral enlightenment of a culture that many times label Black men as beasts." [21]). Dyson goes on the assert that "in our everyday practice, versions of those stereotypes are reborn in images of young black males as social pariahs and older black males as rootless, ruthless ne'er-do-wells." Critical Race theory has also attempted to offer an explanation to why young African American males tend to be targeted and profiled. The Trayvon Martin court case has been used to exemplify how racial profiling and black male stigma aids in perpetuating social inequality and injustice towards black men [22]. These researchers assert that the presupposition that black male youths are violent, aloof, and dangerous is all too often part of the socialization process and cultural narrative in America [22]. With the advent and enforcement of civil rights legislation, open and overt forms of racism and bigotry are not publicly tolerated and are, in most cases, met with immediate and public condemnation [22]. "Suffice to say that now the United States is said to have transformed to a "color-blind society," where methods of maintaining "privilege" cannot overtly appear racially constructed [22]. "Color blindness is associated with the liberal 1970s ideal of learning not to see race or color in an attempt to eliminate personal prejudices and to promote a level playing field" However, as CRT theorists explain, colorblindness as a form of equality, forgoes the salience of racism as an ordinary occurrence in American society [22]. Notions of colorblindness do not account for the long-standing radicalized stigma and discriminatory practices that are all too commonplace for black America" [22]. Critical race theorists have demonstrated that racism
JMHSB, an open access journal 
is routine, not exceptional, and that liberal accounts were inadequate to understand its persistence and power [14]. "Critical Race Theory argues that race permeates much of what happens in between arrest and sentencing, in terms of the charges brought and plea negotiations, and for the small percentage of cases that go to trial, in terms of jury selection and jury biases. Race permeates the back end of our criminal justice system. "The problem of sentencing disparities has not gone away. And the problem of mass incarceration, or rather society's general indifference to it, is largely unintelligible but for race. There is a reason Michelle Alexander describes the mass incarceration of black and brown people as the new Jim Crow; the result, I have observed, is that we now "benefit" by living in newly purged, whiter cities (Alexander, 2012 ) "Today there are more African-Americans under correctional control - in prison or jail, on court-ordered probation or parole - than were enslaved in 1850 , a decade before the Civil War began. As James Forman points out, there is something unsettling about the fact that we incarcerate blacks at a greater rate now than we did at the time of Brown v. Board of Education, and at eight times the rate we incarcerate whites, and that these dwarfs other black/white disparities such as in unemployment (2:1), wealth (1:4), out-of-wedlock births (3:1), and infant mortality (2: 1)" [23].
Although Critical Race Theory has provided many useful insights, it has largely left crime and criminal justice unexplored. At the close of 2017, The national registry of exonerations had compiled a data base detailing 2,372 known exonerations that have been granted to wrongfully incarcerated victims since 1989 . The registry also pointed out that, at that time, more than 20,735 years of human lives have been lost due to an assortment of wrongful convictions [24]. The categories include mistaken witness identification, false confession, perjury or false accusation, false or misleading forensic evidence, official misconduct, and inadequate legal defense. The causes of many of the convictions occurred because of several factors in combination with other factors leading to incarceration. For example, an individual conviction could have been the result of mistaken witness identification, false or misleading forensic evidence and official misconduct simultaneously. Very seldom was an individual convicted because of one single factor alone. It is therefore difficult to ascertain precisely how many of the 2,372 known exonerations in the 2017 data base is attributed to one factor alone. However, when categories are combined, the data yield results that are more meaningful and more statistically relevant (see figure 1). Of the 2,372 exonerations, 38.1 percent are white, 47.8 percent are black, 11.8

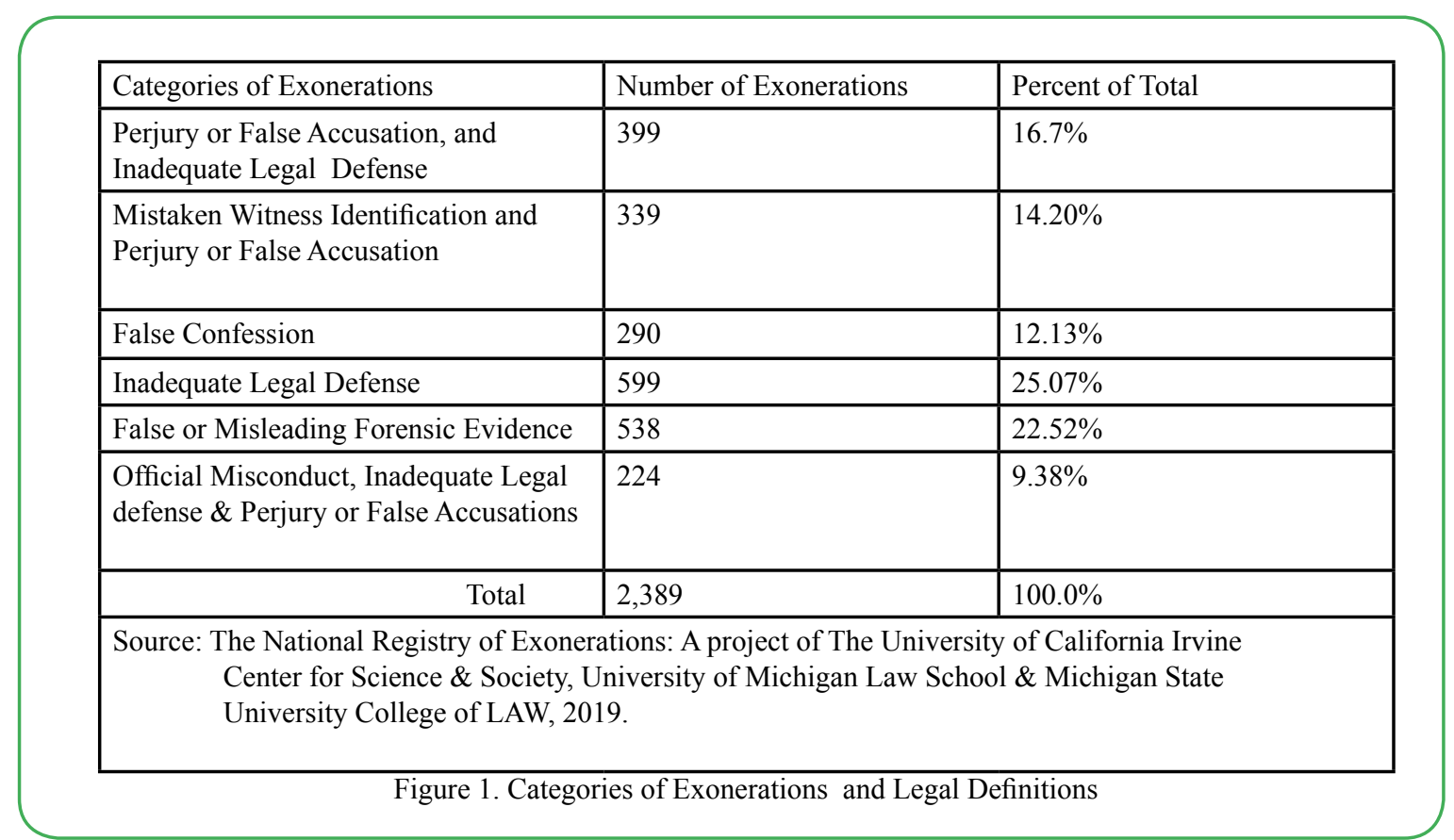

percent are Hispanic and 2.3 percent other. The age of the exonerees range from 11 to 83 , with the overwhelming majority (greater than two-thirds) being between the ages of 18- 30 [25]. This data is somewhat misleading in that it shows that a larger percentage of blacks are exonerated than any other race. What it does not show is the disproportionate percentage of blacks, relative to other races, who are wrongfully convicted in the first place. It is only reasonable to assume if Blacks are disproportionately represented in the number of convictions, they will also be disproportionately represented in the exonerations as well. African Americans are over-represented among exonerations for other crimes as well such as murder, child sex abuse, robbery, and other violent and non-violent crimes. As stated earlier, African Americans are only 13 percent of the American population, but an over whelming majority of the innocent defendants wrongfully convicted of crimes and later exonerated. Blacks constitute 47 percent of the 1,900 exonerations listed in the National Registry of Exonerations as of October 2016, and the great majority of more than 1,800 additional innocent defendants who were framed and convicted of crimes in 15 large-scale police scandals and later cleared in "group exonerations" [3]. There is no one explanation for the heavy concentration of black defendants among those convicted of crimes they did not commit. The causes that have been identified range from inevitable consequences of patterns in crime and punishment to deliberate acts of racism, with many stops in between. For example, overall, African Americans are about five times as likely to go to prison for drug possession as whites, and judging from exonerations, innocent black people are about 12 times more likely to be convicted of drug crimes than innocent white people [3]. Figure 1 outlines the categories of exonerations as well as the number of exonerations given in that category and the percentage of the total of all exonerations granted as of 2017. The 2017 registry does not stratify by race of the defendant. It reveals the number of exonerations and the categories on which the exonerations were based. The data had to be teased in such a manner that one can glean a clearer picture of the pattern of exonerations by category. Although most of the categories had several contributing factors as causes for the exonerations, the categories were limited to three so as to prevent data distortion and present totals that would far exceed 2,373 actual cases of exonerations compiled in the 2017 report. The data in the national registry for 2017 was set up in an excel spread sheet 
and stratified by various categories to produce the results in figure 1 below. If the categories were examined singularly rather than in a grouping of categories, the totals, as stated earlier, would far exceed the 2,379 cases. Therefore, the cases were grouped into various categories and grouped to produce the 2,379 cases.

\section{Official Misconduct}

In this data on the National Registry of Exonerations, when the variable official misconduct is isolated and looked at separately from all the other contributing factors, there are 1,248 cases or 52.6 percent of the cases where victims were exonerated because of official misconduct [25]. Police misconduct refers to inappropriate conduct and or illegal actions taken by police officers in connection with their official duties. Types of official misconduct is far ranging and can include actions that range from coerced false confession, intimidation, false arrests, false imprisonment, falsification of evidence, spoliation of evidence, perjury, witness tampering, corruption, racial profiling, unwarranted surveillance, unwarranted searches, and unwarranted seizure of property, etc. Misconduct can also include prosecutorial misconduct or the inappropriate behavior of trial lawyers and judges that result in wrongful convictions. Needless to say, official misconduct, whether by the police or the lawyers is a major reason that many innocent African American victims get wrongfully convicted. The police have a large amount of administration discretion. That discretion is frequently misused. Convictions of murder that resulted in the exonerations of black defendants were 22 percent more likely to include misconduct by police officers than those with white defendants. On average, black murder exonerees spent three years longer in prison before release than white murder exonerees, and those sentenced to death spent four years longer [3]. For example, in Harris County Texas, where the population is only 22 percent black, 62 percent of the drug crime guilty plea exonerees were African Americans. These are cases in which defendants pled guilty and were exonerated after routine lab tests showed they were not carrying illegal drugs [3]. The best national evidence on drug use shows that African Americans and whites use illegal drugs at about the same rate. Nonetheless, African Americans are about five times as likely to go to prison for drug possession as whites - and judging from exonerations, innocent black people are about 12 times more likely to be convicted of drug crimes than innocent white people. African Americans are more frequently stopped, searched, arrested, and convicted in cases in which they are innocent. The extreme form of this practice is systematic racial profiling in drug-law enforcement [3]. Eddie Glaude, Chairman of the African American Studies Department at Princeton University says "there is little doubt about the evidence of police misconduct. At the end of the day, policing takes us to the heart of the contradictions of race in this country. We have never resolved it. Policing is that site, that space where violence and the ugliness of American racism converge, and it's legally sanctioned by the state"[26].

\section{Mistaken Eyewitness Identification}

When looked at singularly, there were 676 exonerations given on the basis of mistaken identity. This figure, as has been pointed out, is misleading because there were other contributing factors associated with the exoneration other than mistaken identity. This figure does point out the seriousness of mistaken identity in putting innocent people behind bars and in prison. When mistaken identity was examined along with perjury or false accusation, a more definitive picture can now be portrayed as the two together constitute 339 of the 2373 cases or 14.2 percent of the total as can be gleaned from figure 1. Judging from the exoneration data, a black prisoner serving time for sexual assault is three and-a-half times more likely to be innocent than a white sexual assault convict. The major cause for this huge racial disparity appears to be the high danger of mistaken eyewitness identification by white victims in violent crimes with black assailants [3]. Most innocent African American defendants who were exonerated for sexual assault had been convicted of raping white women. The leading cause of these false convictions was mistaken eyewitness identifications - a notoriously error-prone process when white Americans are asked to identify black strangers. As with murder exonerations, however, the leading cause is far from the only one. We see clear evidence of racial bias, ranging from unconscious bias to explicit racism. And, as with murder if not more so, black sexual assault exonerees spent more time in prison than their white counterparts [3]. Assaults on white women by African American men are a small minority of all sexual assaults in the United States, but they constitute half of sexual assaults with eyewitness misidentifications that led to exoneration [3]. Eyewitness misidentifications do not completely explain the racial disparity in sexual assault exonerations. Some misidentifications themselves are, in part, the products of racial bias, and other convictions that led to sexual assault exonerations were marred by implicit biases, racially tainted official misconduct and, in some cases, explicit racism.

\section{Varieties and Causes of False Confessions}

It can be gleaned from the data compiled by the national register of exonerations that there are 290 cases of clear-cut false confessions. This category alone singularly represents 12.13 percent of the total number of exonerations. False confessions are caused by a variety of factors-including those that are unique to an individual, those inherent in interrogation practices, and those that derive from practices that are more coercive than average. The primary factor for innocent confessors is coercion - being "frightened, tricked, exhausted or all three."'" Of the 135 exonerations detailed by the National Registry of Exonerations in 2012, 60 percent (82) were "clearly coerced," 12 percent (16) either denied having made the statements or indicated that their words were not meant to be an admission of guilt,"' and 11 percent (15) of the confessions were apparently voluntary. " Researchers have also categorized confessions into distinct groups to reflect the various phenomena that produce them. Although there continues to be debate surrounding the exact definitions and terms, essentially there are three types of psychological processes that lead to false confessions. These are "voluntary false confessions," "compliant false confessions," and "persuaded false confessions." A voluntary false confession is one that does not involve police inducement. Voluntary false confessions can be either rooted in psychological disorders or be the result of an independent personal motive-for example, to protect the real perpetrator. " "High-profile" crimes often attract confessions from volunteers around the country as well. Laverne Pavlinac's confession is an example of this: she confessed to a crime she did not commit in order to end 10 years of abuse." Although ethically unreliable, voluntary false confessions can often present less of a risk of a wrongful conviction. This is because police and prosecutors are more skeptical of unprompted voluntary false confessions than those produced voluntarily [27].

\section{Perjury or false accusations}

Perjury is the offense of willfully telling an untruth in a court after haven taken an oath or affirmation, a.k.a., lying under oath. When looked at separately from all other causal factors in the exoneration, perjury itself shows up 1,380 times or in over half (57.62 percent) of all exonerations. When false confession and perjury or false accusation are looked at jointly, they comprise 205 or 8.6 percent of the exonerations. This again is due to the high degree of overlap among the various contributing factors of exonerations. However, when examined singularly, there is no other single factor that occurs among the 2,372 exonerations. When looked at singularly or individually, official misconduct comes in a close second appearing as a cause in 1,240 of the identifiable exonerations. Without a doubt, both perjury and official misconduct have resulted in an inordinate amount of imprisonment for crimes that those found guilty did 
not commit. When the truth was unfolded, over 50 percent of those in jail were exonerated. It is no mere coincidence that perjury and official misconduct looms large in murder, sexual assault, and drug crimes. There appears to be a conscious bias among white police officers against black men who are accused of murder, rape, and drug trafficking.

\section{False or Misleading Forensic Evidence}

When this category is looked at singularly, there are 538 cases where exonerations are granted due to misleading forensic evidence. These are cases where lab results came back inconclusive to prove guilt and the victim had to be set free. It is not unusual for DNA evidence to be tampered with as was the crime of the century that resulted in the acquittal of former NFL great O.J. Simpson. Unscrupulous police officers can plant false evidence to falsely convict and send people to prison simply because that is what they do [3]. Sixty percent of the drug exonerations we know about occurred in Harris County, Texas. The defendants in these cases pled guilty to drug possession before the supposed drugs they possessed were tested in a crime lab, and were exonerated weeks, months or years later after testing was done and no illegal drugs were found [3]. Why did these defendants plead guilty even though they possessed no controlled substances? Some may have had powders or pills that they thought contained illegal drugs but did not. As far as we can tell, however, most pled guilty to get out of jail. In a typical case, the defendant had a criminal record and could not post the comparatively high bail that was set. At the first court appearance, the prosecutor made a for-today-only take-it-orleave-it offer to the defendant: plead guilty and go home immediately, or in a few days or weeks. If the defendant pled not guilty, however, he would remain in jail until trial-usually for months, sometimes for a year or longer - and then risk years in prison if convicted. It's hardly surprising that many innocent defendants took the deal [3]. "The only reason we know about these false guilty pleas is that the Harris County and Houston Police crime labs test the materials seized from the drug defendants after they enter guilty pleas" [3]. Few crime labs do that, which means that lab tests are rarely done in routine drug cases, since 95 percent or more of drug possession convictions are based on guilty pleas that are usually entered before lab tests. If crime labs across the country routinely conducted post-plea drug tests, we would learn about thousands of additional false drug convictions in other counties. Thirty-nine percent of the Harris County guilty-plea drug exonerations were misdemeanors (53 out of 133) - compared to 1 percent for the rest of the Registry (18 out of 1,882) [3]. In other words, the Harris County guilty-plea exonerations look a lot more like routine drug prosecutions than the other drug exonerations we know about. The reason is simple: the Harris County drug defendants were exonerated by a fortuity - routine post-conviction drug tests that just happened to show up - rather than as a result of deliberate case-by-case investigations by the defense or the prosecution [13].
Despite the unique setting, the racial composition of the Harris County drug exonerations is familiar: 62 percent of the exonerees are African American in a county with 20 percent black residents, about seven times the rate for other racial groups [13]. Most, if not all of these innocent black defendants in Harris County pled guilty rather than go to trial because it was their best option, given that they had been arrested and charged, and were held in jail.

\section{Data and Methods}

The Data for this study was retrieved from the National Registry of Exonerations for 2017 and 2020. Unlike the 2017 registry, the data base for 2020 are arranged in a spreadsheet that allows for the categories $\mathrm{n}$ be stratified by both age, race, and category of crime. The data reveal racial disparities among all major crime categories, but the three types of crimes that produce the largest numbers of exonerations in the Registry are : murder, sexual assault, and drug crimes [3]. This data is available for all the years beginning in 1989 to the present. Every known case of exonerations is included and on occasion, cases that predate1989, as far back as the 1970s, is included in the data set. The data base contains over 2810 known cases as of 2020. This study is focuses on three crimes alone, murder, attempted murder, and accessory to murder. Obviously, murder is a more serious crime and the one most likely to lead to death row. Sexual assault and drug crimes, although very interesting, may very well be the subject of a subsequent study but this study is stratified by three variables, i.e., race, age and murder. The ages included are 16-year-olds to 19 -year-olds. The study includes predominately teenagers because these are the groups considered more vulnerable irrespective of race. Neither the year in which each individual was incarcerated nor the year in which each exoneree was released were included in this study but instead, the total number of years served were used so as to ascertain an overall mean number of years imprisoned for each cohort group. Females accused of murder are not included in this study. This secondary data analysis examined all cases of murder, attempted murder, and assault for all the ages between 16 and 19. According to the 2020 national registry, there were a total of 35 cases of murder, attempted murder, and assault by 16 -year-olds. (See table 1). Of the 35 16-year-old youths released from prison between 1989 and 2020, twenty-seven or 77 percent were African American and 8 exonerees or 23 percent were White male youths. White males were imprisoned on an average of 19.13 years prior to being exonerated while African American males were incarcerated slightly longer at 20.2 years. For the 16-year-old cohorts, the most alarming findings was not necessarily the difference in the mean number of years served in prison prior to release by the two cohort groups but the vast discrepancy in the number of exonerees who were black rather than white. Logic and reason support the fact that the higher the wrongful conviction rate, the more likely the exoneration rate will be higher also.

\begin{tabular}{|l|l|l|}
\hline RACE & $\begin{array}{l}\text { MEAN NUMBER OF } \\
\text { YEARS SERVED }\end{array}$ & $\begin{array}{l}\text { REASON(S FOR } \\
\text { EXONERATION }\end{array}$ \\
\hline WHITE & $\begin{array}{l}\overline{\mathrm{X}}=18.13 \text { Years } \\
\mathrm{N}=8\end{array}$ & $\begin{array}{l}\text { DNA FC P/FA ILD OF } \\
\text { WH PJ }\end{array}$ \\
\hline $\begin{array}{l}\overline{\mathrm{X}}=20.2 \text { Years } \\
\mathrm{N}=27\end{array}$ & $\begin{array}{l}\text { MWID DNA P/FA OM } \\
\text { ILD PR FC NW KP WT } \\
\text { WH OM }\end{array}$ \\
\hline BLACK & $\begin{array}{l}\text { Source: The National Registry of Exonerations. Center for Science and Society at } \\
\text { University California Irvine, the University of Michigan Law School and Michigan } \\
\text { State College of Law, 2021. }\end{array}$ \\
Table 1. 16-YEAR-OLD MALES IN THE UNITED STATES WRONGLY \\
CONVICTED FOR MURDER, ATTEMPTED MURDER, ACCESORY TO MURDER \\
AND LATER EXONERATED SINCE 1989 \\
\hline
\end{tabular}


When the data in table 2 is examined for the 17 -year-old cohort group, , a similar pattern is discerned. There was a total of fifty- nine 17-year-old cohorts in this group There were 11 white 17-year-olds or 18.64 percent exonerated as compared to 48 black 17 -year-olds or 81.4 percent. The mean number of years spent behind bars for the white 17-year-old cohort was 18.2 years while the mean number of years served prior to exonerations of the blacks 17-year-old was 18.5 years. The pattern persists where the overall number of African American exonerees were five times larger than their white counterparts in the population. Although the means number of years served prior to exoneration between the white and black 17-year-old is discernible, the most alarming discrepancy is the differential in the total number of young blacks incarcerated and later freed as opposed to young 17-year-old whites males.

\begin{tabular}{|l|l|l|}
\hline RACE & $\begin{array}{l}\text { MEAN NUMBER OF } \\
\text { YEARS SERVED }\end{array}$ & $\begin{array}{l}\text { REASON(S FOR } \\
\text { EXONERATION }\end{array}$ \\
\hline WHITE & $\begin{array}{l}\mathrm{X}=18.20 \text { Years } \\
\mathrm{N}=11\end{array}$ & $\begin{array}{l}\text { DNA FC P/FA ILD } \\
\text { OF WH PJ PR OM }\end{array}$ \\
\hline BLACK & $\begin{array}{l}\mathrm{X}=18.5 \text { Years } \\
\mathrm{N}=48\end{array}$ & $\begin{array}{l}\text { MWID DNA P/FA } \\
\text { KM WTD PR FC NW }\end{array}$ \\
\hline $\begin{array}{l}\text { Source: The National Registry of Exonerations. Center for Science and } \\
\text { Society at University of California Irvine, the University of Michigan Law }\end{array}$ \\
$\begin{array}{l}\text { School and Michigan State College of Law, 2021. } \\
\text { Cable 2. 17-YEAR-OLD MALES IN THE UNITED STATES WRONGLY }\end{array}$ \\
MUNVICTED FOR MURDER, ATTEMPTED MURDER, ACCESORY TO \\
MURER AND LATER EXONERATED SINCE 1989
\end{tabular}

Careful examination of the data in Table 3 for the 18-year-olds display a similar pattern in terms of the mean number of years served as well as the glaring discrepancy in the total number of black verses white exonerees. The table shows the mean number of years of incarceration prior to being exonerated between black and white youth who are 18 years of age is significantly different, 14.46 years for Whites verses 16.82 years for Blacks. That is a difference of 14 percent. However, this pales in comparison to the disturbing pattern in the number of 18-year-old Blacks, 46 out of 61 , or 75.4 percent were exonerated as compared to 15 out of 61 or 24.6 percent for whites. This also approximates the pattern whereby Blacks in the criminal justice system are incarcerated at 5 times or greater than the rate for their white counterparts.

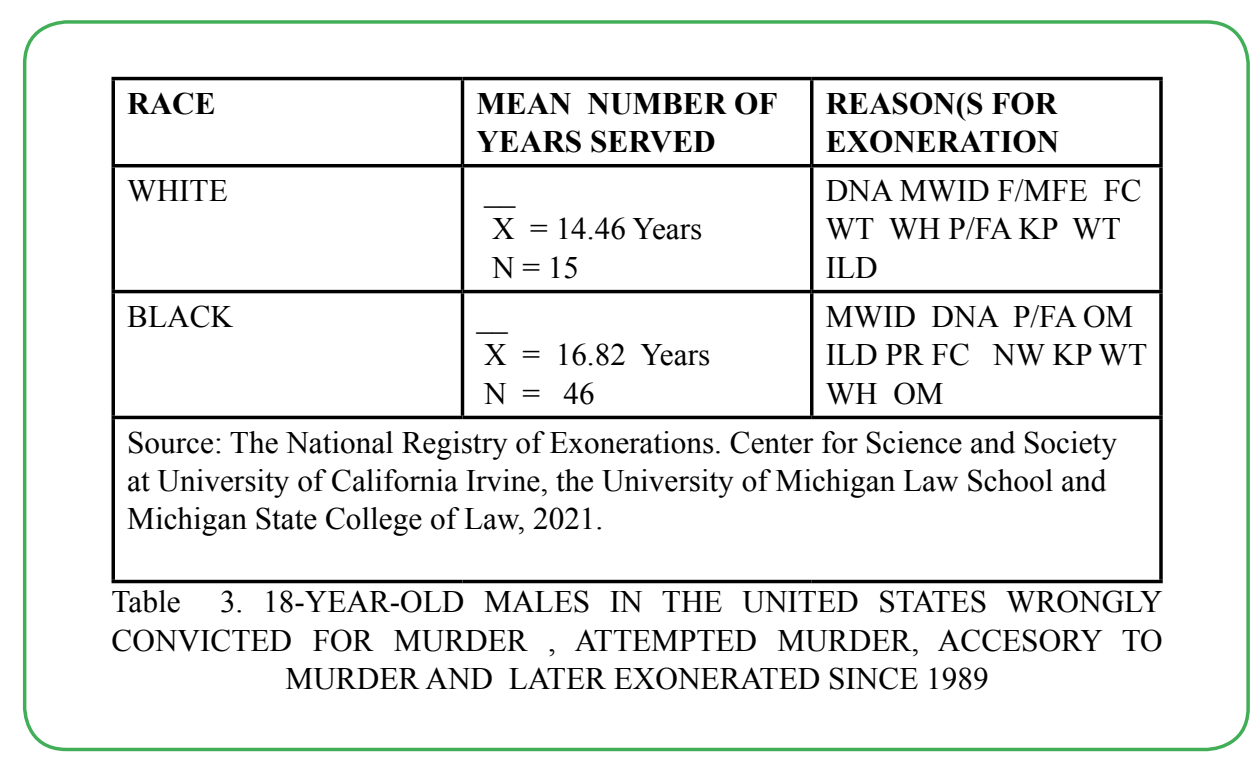

The final cohort group examined in this study were the 19-yearolds. Disturbing but not surprising, the overall pattern in terms of mean number of years served as well as the number of exonerees for both races remain consistent. Black youth were nearly 5 times more likely to be imprisoned. Out of the total of 73 convicted for murder or attempted murder or accessory to murder among the 19-yearold cohort, 60 exonerees out of a total of 73 or 82.2 percentwere black males compared to 13 or 17.8 percent were white male 19-year-old. The mean number of years served was also significant. White males were imprisoned on an average of 17.7 years prior to release while black male youth were detained on an average of 20.8 years. This is a 14.9 percent difference. Again, there is no plausible explanation for the difference, but it does appear that race is the major contributing factor. 


\begin{tabular}{|l|l|l|}
\hline RACE & $\begin{array}{l}\text { MEAN NUMBER OF } \\
\text { YEARS SERVED }\end{array}$ & $\begin{array}{l}\text { REASON(S FOR } \\
\text { EXONERATION }\end{array}$ \\
\hline WHITE & $\begin{array}{l}\mathrm{X}=17.7 \text { Years } \\
\mathrm{N}=13\end{array}$ & $\begin{array}{l}\text { DNA FC P/FA ILD OF } \\
\text { WH PJ OM }\end{array}$ \\
\hline BLACK & $\mathrm{X}=20.8$ Years \\
$\mathrm{N}=60$ & $\begin{array}{l}\text { MWID DNA P/FA OM } \\
\text { ILD PR FC NW KP WT } \\
\text { WH OM }\end{array}$ \\
\hline
\end{tabular}

Source: The National Registry of Exonerations. Center for Science and Society at University of California Irvine, the University of Michigan Law School and Michigan State College of Law, 2021.

\author{
Table 4. 19-YEAR-OLD MALES IN THE UNITED STATES WRONGLY \\ CONVICTED FOR MURDER, ATTEMPTED MURDER, ACCESORY TO MURDER \\ AND LATER EXONERATED SINCE 1989
}

\section{Summary and Policy Implications}

It is widely known that our criminal justice system is in dire need of reform. It is also generally understood that while Americans comprise slightly less than 5 percent of the population of the entire world, the home for more than 25 percent of convicted felons in the world are housed in prisons in the United States of America. This does not appear to be a very auspicious revelation considering the fact that the U.S.A. is still considered the greatest nation in the free world. This study provides evidence that manpower waste and the reduction in one's quality of life have been less than promising in a nation that leads the free world. It is inauspicious when so many of our youth are imprisoned as children for frequently crimes that they did not commit and return to society as middle-aged adults if they are fortunate enough to have their case heard and receive vindication. This youth from the ages of 16 to 19 employing the National Registry of Exonerations for 2020. Although the major focus of this study is on exonerations, convictions are also involved because an exoneration cannot occur without their first being a conviction. This data base or national registry provides detailed information about every known exoneration in the United States from 1989 to the present. One particular finding, although not surprising, is the statistics which show that the older one gets, the greater the number of murders committed. Although the cut off age for this study is 19 -year-olds, a subsequent study adding more ages to the analysis to include more adult males would obviously be an interesting sub-population Judging from more likely to be convicted of murder than innocent white young males. African American prisoners who are convicted of murder are about 50 percent more likely to be innocent than other convicted murderers [3]. Part of that disparity is tied to the race of the victim. African Americans imprisoned for murder are more likely to be innocent if they were convicted of killing white victims. Only about 15 percent of murders by African Americans have white victims, but 31 percent of innocent African American murder exonerees were convicted of killing white people. Most wrongful convictions are never discovered and there is no direct measure of the number of all convictions of innocent murder defendants; however, judging from exonerations, half of those innocent murder defendants are African Americans [3]. Judging from exonerations, innocent black people are about seven times more likely to be convicted of murder than of murder are about 50 percent more likely to be innocent than other convicted murderers [3]. Part of that disparity is tied to the race of the victim. African Americans imprisoned for murder are more likely to study provides an analysis of exonerations of white and black male exonerations, innocent black young men are about seven times innocent white people. African American prisoners who are convicted

be innocent if they were convicted of killing white victims. One particular case used as a benchmark for this study has received national attention recently due to the vigilance and involvement of one of our nation's greatest female athletes in both college and the Women's National Basketball Association ( WNBA). Maya Moore became interested in a 16-year-old male, named Jonathan Irons, that was convicted in 2005 for attempted robbery and assault. Maya used her platform and started a social action campaign called Win with Justice to try to free Mr. Irons, whom she learned about via her extended family while she was completing a stellar career at the University of Connecticut's Collegiate basketball program. From there, she was developing a hall of fame career in the WNBA with the Minnesota Lynx until she decided to devote all of her time to securing the release of Mr. Irons. This has become a high-profile case as it has shed light on the dire need of prosecutorial reform in general and criminal justice reform in particular in our American system of justice. Her resources and her platform paid dividends as she was able to assist in securing his release from prison by getting his convictions overturned by a Cole County Judge in Jefferson City Missouri. Iron was 16 when he was tried as an adult and convicted of breaking into a home and twice shooting a homeowner and sentenced to 50 years. On March 9, 2020, the Circuit Court ruled that prosecutors suppressed fingerprint evidence that would have strengthened Irons' defense and presented no physical proof linking him to the crime. Also, the testimony of an eyewitness was "dotted with inconsistencies" the judge said., After the evidence was presented by Iron's attorney, the state prosecutors declined to retry the two decade-old burglary and assault case (nbcnews.com.2020). This case highlights the need for serious prosecutorial reform in our criminal justice system. Maya More said she was educated on the needs of such reform. She learned that in the United States, most prosecutors are elected by the people and have absolute immunitymeaning that they cannot be sued for misconduct in the courtroom even in cases where they have presented falsified evidence or coerced a witness. Also, many of these state prosecutors run for the office by campaigning on a strong law and order platform promising that they will get convictions and keep perpetrators in jail for long periods of time, in many cases with no possibility of parole. Prosecutorial misconduct, police misconduct, inadequate legal defense, false or misleading evidence, mistaken identity, false confession, forced confessions as well as unreliable or inadmissible forensic evidence usually result in long prison sentences. This is why Critical Race Theory is so vitally important. But Critical Race Theory is not alone in providing a theoretical context for understanding this historical egregious practice against primarily people of color. Other plausible theories include: Conflict Theory, Race-Based Conflict Theory, Racial 
Threat Theory and Petit Apartheid Theory. All of these theories provide a context and a framework for studying how racism is embedded in laws and policies that give rise to myriad systemic inequities. Opponents of Critical Race Theory, in particular, as a curricular subject being taught in grades $\mathrm{k}-12$, argue that white children should not be made to feel guilty for being white and this writer agrees totally. But where this author takes exception lies in the fact that young white children have to be taught the meaning of racial profiling, systemic racism, cultural bias, rational racism, and white privilege at a young age because they too will someday become police officers, state and federal prosecutors, judges, and other professionals who work in the criminal justice system and maintain a great deal of administrative discretion. This is not about making anyone feel guilty of the color of their skin or their race and /or ethnicity, but to become educated in the practices and processes of a racist historical past so they will not be prone to make the mistakes of the past and build a more equitable social, just, and bright political future. This is really more about racial and cultural history in a nation with and negative past rather than about Critical Race Theory. Critical Race Theory, as well as all the other theories, are only frameworks within which to couch a formal discussion in our classrooms and educational institutions to develop a greater appreciation for cultural diversity, social justice, racial equality, and equal justice under the law. Since 1989, young men have been robbed of more than 2,500 years of their lives wasted behind bars for being convicted of crimes that they did not commit. The overwhelming majority of them lacked the resources, the education, the access and financial wherewithal to secure a new trial that presents the true facts of the case that has the potential to set them free. Criminal Justice Reform is a complicated long- term process that must take a multidimensional approach requiring extensive education and training. There has to be buy in from all parties involved. There has to be a mind -set shift by all stake holders, including parents and children. First, voters must be educated to understand the power they wield in voting for district attorneys and prosecutors who have the power and authority to determine the outcome of a case after an arrest has been made. Both the arresting officers as well as the criminal prosecutors must understand and internalize that not all persons are bad people. Many are great people who make bad decisions. Others mistakenly got caught up in the wrong crowd. Everybody must see the good and the potential in others rather than the bad. Criminal Justice Reform must include a provision whereby prosecutors must be held accountable for misconduct that leads to the incarceration of innocent defendants regardless of race. When they mispresent their defendants through illegal tactics such as forced confessions, perjury, withholding pertinent information that they know will have a decisive impact on the outcome or the verdict, they must be held accountable, legally, morally, and practically, and not be immune from criminal prosecution when they willingly and knowingly make mistakes to get innocent people sentenced. Reform must include a provision that prohibits a young defendant from meeting with a prosecutor alone, without both their parents and their lawyer or legal representative present. The judge ruled, rightly so in the Irons case, " that the suppression of exculpatory evidence by the prosecution violated Iron's due process where the evidence is material either to guilt or to punishment." As a result, the presiding judge denied an appeal by the Assistant Missouri Attorney General who argued that the Court exceeded its authority by vacating Iron's sentence. Our great nation has a shameful past in this regard and the time for bringing about reform is now. The law may be colorblind, but people are not. "The question remains, therefore, whether the law can truly exist apart from the color-conscious society in which it exists as a skeleton devoid of flesh; or whether it is the embodiment of society; the reflection of a particular citizenry's arranged complexity of relations [28]. We are a nation governed by constitutional due process of the law and no one should be exempt from that law including Attorney Generals, State Prosecutors, District Attorney, Presiding Judges or the arresting police officers. Accountability must remain paramount if justice is to be served.

\section{TAGS:}

$\mathbf{F C}=$ False Confession

MWID $=$ Mistaken Witness Identification

$\mathbf{P} / \mathbf{F A}=$ Perjury of False Accusation

ILD=Inadequate Legal Defense

$\mathbf{O M}=$ Official Misconduct by Police, Prosecutors of other government officials

WT=Witness Tampering

$\mathbf{P J}=$ Perjury by Official

WH=Withheld Exculpatory Evidence

$\mathbf{O F}=$ Police Officer Misconduct

$\mathbf{K P}=$ Knowingly Committed Perjury

$\mathbf{P R}=$ Prosecutorial Misconduct

F/MFE $=$ False or Misleading Forensic Evidence

$\mathbf{J I}=$ Jail House Informant

DNA=Deoxyribonucleic Acid (used most frequently in homicide cases involving sexual assault

Conflict of interests: The authors declare no conflict of interest.

\section{References}

1. Saloon, Stephen. (2010). Race and Wrongful Convictions. Innocence Project. https://innocence project.org/race-andwrongful convictions.

2. Clarke, Matt (2020) Racism and Wrongful Convictions; Criminal Legal News.

3. Gross, Samuel, Possley, Maurice, Stephen, Klari. (2017). Race and Wrongful Convictions in the United States. National Registry of Exonerations: Newkirk Center for Science and Society. University of California Irvine.

4. Alexander, Michelle. (2019). The New Jim Crow: Mass Incarceration in the age of Color Blindness, Penguin Books.

5. Domonoske, Camila. (2016). :U.S. Appeals Court Finds Texas Voter ID Law Discriminates Against Minority Voters." National Public Radio. July 20. (https://www.npr.org/sections/ thetwo-way/2016/07/20 486776853/u-s-appeals-court findstexas-voter-id-law discriminates-against-minority-voters).

6. Evans, Rhonda. ."When They See us" Researching the Story of the Exonerated 5 and Beyond at the New York Public Library. Research and Reference Division, Schomburg Center for Research in Black Culture, June 25, 2019. Bibliophile, Paperless Research. https://www.nypl.org/blog/2019/06/25/when theysee-us-researching-story-exonerated-five-and-beyond-newYork-public.

7. Calamus, Krishnadev, "Alabama Pardons Scottsboro Boys in 1931 Rape Case”, npr.org, 2013.

8. Blalock, H. M. (1967). Toward a theory of minority-group relations. New York: Wiley.

9. Anderson, James F., Kelley Reinsmith-Jones, Willie Brooks, Jr. (2016). Black Shootings, Conflict Theory, and Policy Implications. International Journal of Science Studies, 5(4); May. ISSN 2324-8033 E-ISSN 2324. 8041.Redfame Publishers.

10. Gibbs, Jewelle Taylor, ed. (1988). Young, Black and Male in America: An Endangered Species. New York, Greenwood Publishing Group. 
11. Turk, A. (1969). Criminality and Legal Order. Chicago: Rand McNally. York.

12. Chambliss, W.J., \& Seidman, R. (1982). Law, Order, and Power. Reading, MA: Addison-Wesley.

13. Quinney, R. (1977). Class, State, and crime: on the theory and practice of criminal justice. New York: Longman.

14. Delgado, Richard. \& Jean, Stefanic., (2007). Critical Race Theory and Criminal Justice, Journal of Humanity \& Society, Vol 31. Issue 2-3. Retrieved from https://doi. org/10.1177/016059760703100201.

15. Simba, Malik. (2017). Critical Race Theory. Salem Press Encyclopedia.

16. Subotnik, Dan. (2017). The Dangers of Racial Thinking. Springer-Science +Business Media New

17. Atkinson, M.P., Korgen, K.O., \& Trautner, M.N. (2021). Social problems : sociology in action.

18. LaFraniere, Sharon., and Andrew, W. Lehren. (2015). "The Disproportionate Risks of Driving While Black." New York Times. Retrieved July 15, 2020. (http://www.nytimes. com/2015/10/25/us/racial-disparity-traffic-stops-driving-black. html).

19. Mueller, B., Robert, G., and Chinoy, S. (2018). "Surest Way to Face Marijuana Charges in New York: Be Black or Hispanic." New York times, May 13 ((http://www. nytimes. com/2018/05/13/nyregion/marijuana-arrests-nyc-race.html).

20. Milovanovic, Dragan, Katheryn K. Russell-Brown (2001). Petit Apartheid in The U.S. Criminal Justice System: The Dark Figure of Racism; Carolina Academic Press, 2001.
21. Dyson, Michael Eric (1996). Race Rules: Navigating the Color Line. New York: Addison-Wesley.

22. Teasley, Martell Lee, Jerome H. Schiele, Charles Adams, Nathern Okilwa, (2018). Trayvon Martin: Racial Profiling, Black Male Stigma and Social Work Practice. Vol. 63, Issue 1, January. Retrieved from https://doi.org/10.1093/sw/swx049

23. Capers, Bennett, (2014). Critical Race Theory and Criminal Justice, Ohio State Journal of Criminal Law, vol, 12:1. Retrieved from https://kb.osu.edu/dspace/bitstream/handle/1811/73470/ OSJCL_V12N1..

24. D. Michael Risinger (2007). Innocents Convicted: An Empirically Justified Factual Wrongful Conviction Rate. Journal of Criminal Law and Criminology, vol. 97, Issue 3., Article 3. Spring.

25. National Registry of Exonerations; Newkirk Center for Science and Society. University of Michigan Law School and Michigan State University College of Law. Retrieved from https://www.law.umich.edu/special/exoneration/Pages/ ExonerationsRaceByCrime.aspx

26. Glaude, Eddie, (4/20/2021). MSNBC interview by Lawrence O'Donnel, Jr. Policing in America .

27. Du Clos, S. (2014). Lessons from State V. Lawson: The Reliability Framework Applied to Concessions and Admissions. Lewis \& Clark Law Review, 18(1), 227-270. Retrieved from http://proxygsu-.galileo.usg.edu/login?url=http://search. ebscohost.com/login.aspx?direct=true $\& \mathrm{db}=\operatorname{lgs} \& A N=9637938$ $8 \&$ site $=$ eds-live $\&$ scope $=$ site

28. Williams, L.J., Anderson, S.E., (1991). Job Satisfaction and Organizational Commitment as Predictors of Organizational CitizenshipandIn-RoleBehaviors. JournalofManagement, 17(3), https://doi.org/10.1177/014920639101700305. 